\title{
Krig, jubel og \\ uretfærdighed i Maurice Blanchots L'instant de ma mort
}

\section{Fra fraktur til jubel}

At læse Maurice Blanchot er en oplevelse, der adskiller sig fra alle andre læseoplevelser, siger Paul de Man et sted. ${ }^{1}$

Blanchot, som er født 1907, tilhører i fransk tænkning samme store generation som bl.a. Georges Bataille, og Émmanuel Lévinas, og han deler dermed dens baggrund: på den ene side en dyb inspiration fra tysk idealisme og fænomenologi (Hegel, Husserl, Heidegger) og på den anden side voldsomme indtryk fra 2. verdenskrig. Al metafysisk interesse brødes her af krigens brutale udhuling af selve grundlaget for metafysisk erfaring. Hos Blanchot indebar denne baggrund, at han kom til at dele anliggende og ærinde med Bataille og Lévinas, men derudover finder man også en blanding af noget ligefremt og samtidig helt obskurt i hans forfatterskab. I det følgende vil jeg beskrive denne kombination af fællespræg og særpræg med udgangpunkt i en usædvanlig tekst, erindringsskitsen L'instant de ma mort, ${ }^{2}$ der kan betragtes som en art miniatureroman.

Det er ikke så ligetil at genrebestemme Blanchots skrifter. Han opererer selv med betegnelsen »récit» (fortælling) eller »écriture» (skrift), som kontrasteres med roman og novelle og bog. Fortællingen og skriften optræder her som skriftgenrer, der på den ene side kan siges at befinde sig et spadestik dybere end eller "udenfor $\mathrm{fx}_{\mathrm{x}}$ romanen og novellen, og på den anden side dermed kan anskues som varianter af en art generaliseret skrift, for nu at genbruge Derridas gamle udtryk. Forfatterskabet er notorisk spændt ud i et

1. »Impersonality in Blanchot« (org. 1966), optrykt i de Man: Blindness and Insight, 2.ed., London 1989, p. 62. 
minefelt mellem de såkaldte »fortællinger«, romaner, anmeldelser af helt usædvanlig kaliber, og tungtvejende essays og refleksioner. Grænsen mellem det fortællende og det tænkende er ofte hårfin, og den krydses ikke sjældent i en kryptisk form. For så vidt giver det næppe mening at diskutere, hvorvidt Blanchot i et givet tilfælde har skrevet en "roman«, et »essay«, en "novelle» eller fx en »fortælling«, og han har da også selv anvendt udtrykket »désoeuvrement«, som betyder ørkesløshed, men også har en medbetydning af "afværkning«. Han lægger dermed afstand til selve ideen om det afrundede værk eller den sluttede romanverden. Til gengæld giver det god mening at diskutere Blanchot i forhold til spørgsmålet om romanens udvikling i det 20. århundrede, hvor hans kredsen om dødserfaringen sættes i relief af den behandling, som dette tema får hos forfattere som Broch, Bataille, Beckett og Borges. ${ }^{3}$

Så meget desto mere, som Mit dødsøjeblik direkte konfronterer og repeterer det politiske fænomen (nazismen) under 2. verdenskrig, samtidig med, at teksten umiskendeligt er præget af det, der er blevet betegnet som Blanchots "retrait politique«, en tilbagetrækning fra det politiske. ${ }^{4}$

Blanchots erindringsskitse er flækket på kryds og tværs af en lang række brud: Mellem det erindrende nu og den erindrede fortid, mellem den oprindelige »han« og det nutidige »jeg«, mellem erindring og narration, mellem det indre og det ydre, mellem mening og viden, mellem det empiriske og det essentielle.

Mit ærinde består i at vise, hvorledes disse skillelinjer løber sammen i en hel og helet jubel, på fransk »l'allegresse«. ${ }^{5}$ Blanchots L'instant frembyder et problematisk spektrum af angiveligt uoverkommelige brudflader, men til slut indsættes der i den et ubrudt og enhedsligt kontinuum, der er uberørt af

2. (Dansk: Mit dødsøjeblik). Blanchot: L'instant de ma mort, Paris 1994; samt The Instant of My Death, Stanford, California 2000 (tosproget udgave). Jeg refererer i det følgende til den franske originaludgave fra 1994, der herefter forkortes $L ' i$. Alle oversættelser fra fransk er mine. Jeg skal nævne, at L'instant opretter et intrikat spil mellem liv og skrift. Af Derridas Demeure (optrykt som følgetekst til den tosprogede udgave) fremgår det, at Blanchot i teksten genkalder sig en autentisk, selvbiografisk hændelse (i brev til Derrida dateret 20.juli 1994, op.cit., p.52). Teksten er med andre ord funderet på en empirisk virkelighed, og er en erindring heraf. Men overfor dette sætter Blanchot sin egen anonymitet og upersonlighed samt et speget forhold mellem det empiriske og det essentielle. Det, Blanchot anfægter, er med andre ord ikke, at hændelsen fandt sted, og at den lader sig genfortælle. Ej heller hævder han implicit eller eksplicit at "alt er text«, eller lignende. Men han forsyner den oprindelige hændelse med et refleksionsarbejde der rejser tvivl om, præcis »hvad « der egentlig foregik, og nøjagtig hvilken mening vi kan og skal tilskrive det hændte.

3. Cf. S.W. Goodwin \& E. Bronfen (eds.): Death and Representation, Baltimore 1993, for en række gedigne fortolkninger af dette problemkompleks.

4. Jfr. Jeffrey Mehlman: Vie et œuvre de Maurice Blanchot: Le partage du mythe, in: Critique, no.630 (1999), pp. 942-952.

5. Cf.: »Jeg ved - ved jeg det - at den som tyskerne allerede sigtede på, mens han kun ventede på den endelige ordre, da oplevede en følelse af ekstraordinær lethed, en slags lyksalighed (dog intet lykkeligt derved), - suveræn jubel?«, $L^{\prime} i$, p.10. 
distancen og traumet. Ikke en forsonet enhed, vel at mærke, men en neutral og indifferent fiktionsverden, gennemsyret af en kølig, utrættelig glæde.

Hvis vi antager, at teksten er delt over på midten, kan der være grund til indledningsvis at inspicere den ene side først, lad os kalde den forsiden.

\section{Parafrasens empiri}

Denne forside er, som altid hos Blanchot, såre simpel. En anonym førstepersons fortæller erindrer i et glimt, hvorledes en ung mand, der måske, måske ikke, er fortællerens yngre alter ego, en dag under 2. verdenskrigs sidste tid i Frankrig abrupt kaldes ud fra sin slægts ejendom af en lille deling desperate nazister, på flugt fra de indtrængende, allierede tropper. Nazisterne hærger, brænder og myrder på den lokale egn, og delingen gør sig parat til at henrette den unge mand samt de få kvindelige slægtninge på »Slottet«, som det med kafkask ironi kaldes. Det lykkes den unge mand at få frasorteret kvinderne, så kun han selv står for tur. Men i sidste øjeblik afbrydes den planlagte henrettelse af geværild i nærheden. Den unge mand, der forbliver navnløs, får af de tiloversblevne soldater lov til at stikke af, han styrter ud i en lokal skov, genvinder sansen for virkeligheden, »le réel«, vender tilbage til slottet, men blot for at konstatere at egnens bønderkarle er myrdet og gårdene er nedbrændt - kun slottet og adelsfamilien er sparet.

Dette glimt suppleres af en kort, afsluttende notits der fortæller om hvorledes den unge mand, der konsekvent omtales i tredje person ental, senere mødte André Malraux i Paris. Malraux kunne berette at han selv var undsluppet fra fangenskab, og havde tabt et manuskript, der dog let kunne rekonstrueres, og fortælleren lukker umiddelbart derefter skitsen med en kryptisk afslutningssalut, der siger: „Qu'importe. Seul demeure le sentiment de légèreté qui est la mort même ou, pour le dire plus précisement, l'instant de ma mort désormais toujours en instance. «. Hvilket oversat lyder omtrent sådan her: "Hvad betyder det. Det eneste der resterer, er den følelse af lethed, der er døden selv, eller, for at sige det mere præcist, min døds øjeblik herefter for altid for retten«. Den sidste vending er ganske tvetydig: "en instance« kan som adverbium betyde »stillet i bero«, mens det indenfor særlig juraen kan angive en proces eller en retsinstans. At være stillet for (stand)retten er på den ene side en konstant proces der aldrig helt kan afbrydes, og på den anden side et momentant øjeblik, der sker for den unge mand hos Blanchot. Det viser tilbage til Kafkas Foran Loven, hvor den ventende mand foran porten aldrig helt er fri for at være på vej til at blive stillet for retten. ${ }^{6}$ 
Den nøjagtige betydning er vigtig at udtyde, fordi den rummer et centralt spil mellem titlens »instant« og dette »instance«. Og dette punkt markerer på samme tid tekstens anden side af den bastante række af brudflader, lad os kalde den for bagsiden.

Holder man sig strikt og pragmatisk til den parafrase jeg netop har leveret, er L'instant at forstå som et vidnesbyrd om og en genfortælling af en sandsynligvis selvbiografisk hændelse under 2 . verdenskrigs sidste dage.

Skitsen kan da i overenstemmelse med en gængs tænkemåde begribes som beretningen om et vendepunkt $\mathrm{i}$ fortællerens liv. Ved at blive konfronteret med, men samtidig undslippe dødens umiddelbare og akutte nærvær - rykket frem fra en diffus fremtid til en ubehageligt klar og vel afgrænset nutid - udstyres den unge mand med en ufravigelig følelse af lethed. Han er herefter udmærket klar over, at døden hvert øjeblik står for døren, men netop denne indsigt gør, at han kan leve livet lettere, mere frit og ubesværet, mindre angst og neurotisk. Derfor gør det ikke så meget, at Malraux’ manuskript er gået tabt - livet er kort og kunsten lang, og han kan jo bare skrive et nyt, hvilket han da også gjorde. Og letheden er formentlig dyrekøbt, og sker ikke kun på Malraux' vegne, for Blanchot har meget diskret indflettet at nazisterne gennemsøgte slottet og intet fandt, undtagen: "papirer, og en art tykt manuskript - som måske indeholdt krigsplaner« ( $L$ 'i, p. 6), papirer der straks afbrændes - et plausibelt gæt ville her være, at det er den unge mands eget bogmanuskript, der i lighed med Malraux' rummer refleksioner over kunsten og litteraturen, og at mandens lethed og ironi (rummer krigsplaner) derfor er gennemgribende og symmetrisk, ikke blot lokal og asymmetrisk.

Tilbage står ikke desto mindre en lille, ligefrem erindrings senere gengivelse.

Denne læsemåde er radikalt forfejlet. At og hvorfor den går galt i byen, står hurtigt klart hvis vi vender os til den anden side af tekstens brudflade.

\section{III. Øjeblikkets cæsur - fra eksistens til essens?}

For det første er det i det temporelle register åbenbart, at der sker flere afvigelser fra det Heidegger kaldte den »vulgære«, dvs. lineære tidsopfattelse. I netop det øjeblik den unge mand står for at blive skudt, overvældes han af en følelse af uforklarlig lyksalighed: »oplevede da en følelse af ekstraordinær

6. Cf. Frederik Tygstrup: »Foran loven. Nogle linjer i Maurice Blanchots forfatterskab«, in Den Blå Port, nr. 11 (1989). 
lethed, en slags lyksalighed (dog intet lykkeligt derved), - suveræn jubel? Dødens møde med døden?«(L'i, p. 4).

Denne bemærkelsesværdige beskrivelse af en tilstand afbrydes som nævnt af geværild, nazi-officeren fjerner sig for en kort stund, og de tilbageblevne soldater stivner: »Tyskerne blev på deres plads, beredte på at forblive sådan i en ubevægelighed, der standsede tiden« (ibid.). Jeg vil forbigå det subtile ekko mellem »restaient en ordre« og »en instance», denne relation lige overfor Loven, og slå ned på det tidslige aspekt.

Der står bogstaveligt at soldaterne var parate til at forblive i en stilstand, der standsede tiden, og at dette skete i og med et øjeblik: »I det øjeblik« ( $L^{\prime} i$, p. 4). Tidens lineære flyden afbrydes her brat, og afløses af et momentant snit. Resultatet er et ekstra-tidsligt vakuum, en ubevægelighed og tomhed der er essentielt fjernet fra tidens sædvanlige gang. At tiden standser, betyder at den koncentreres i et punkt, et øjeblik.

Ovenfor beskrev fortælleren den unge mands sindstilstand som: „Død udødelig. Måske ekstasen« (ibid.). Selve døden må antages at være karakteriseret ved en art utidslighed, ved tidens konkrete og uigenkaldelige fravær, indkapslet i Epikurs lille sofisme, der siger at når døden er, er vi ikke, og når vi er, er døden ikke.

At tiden momentant standser, indebærer at den unge mand midlertidigt opholder sig udenfor livets hverdagslige temporalitet, og hen-rykket i dødens a-kroni, dens udødelighed. Øjeblikkets standsning, dets sammentrækning i et punkt, markerer da en udgang fra tidens normale, lineære flyden fra et før, henover et nu, frem mod en fremtid.

Det græske »ekstase« betyder netop at være borttryllet, at være fjernet fra et sted eller en stilling - med en langt senere tilføjelse af affektive konnotationer i retning af begejstring eller glæde.

Det jeg gerne i første omgang vil understrege, er bruddet med den empiriske eller historicistiske »common-sense« forståelse af tid, som det indledende referat abonnerede på.

I tekstens første etape gør fortælleren omhyggeligt opmærksom på, at dette øjeblik på samme tid for altid ændrede den resterende del af den unge mands livsforløb, og forblev ubegribeligt: »Jeg ved, jeg forestiller mig at denne ikke analysérbare (inanalysable) følelse forandrede det, der resterede for ham af eksistens« ( $L^{\prime} i$, p. 8). Den sidste sætning er central, fordi den tilspidser forholdet mellem »instant« og »instance«. Øjeblikket er unddraget hermeneutisk appropriation og intuitiv erfaring, mens "toujours en instance» betegner en betoning af ufravigelig og uundslippelig nedsænkning i erfaringens resterende domæne.

Men det er ikke uden videre sådan, at »instant « kausalt leder til »instance» - at øjeblikkets ekstase er det der åbner for indgangen til den problematiske 
og uopløselige følelse af lethed. Det ville nemlig medføre, at han var gået fra eksistens til essens: Fra at have været bebyrdet med eksistensens tunge klods om benet (forgængeligheds-erfaringen) skulle han da være frigjort til essensens kontemplative og udødelige region. For der står udtrykkeligt: »det, der resterede for ham af eksistens ( $L^{\prime} i$, p. 8, min understregning).

At denne sondring ikke er vilkårlig, vidner referencen til Georg Wilhelm Friedrich Hegel om. Tekstens fortæller søger et sted at forklare det forhold, at kun slottet blev skånet for nazisternes mordbrande, med, at de tyske banditter nærede en anakronistisk respekt for aristokratiet - men tilføjer, at endnu en specifik årsag kan have været, at den tyske officer var kultiveret nok til at kende Hegels berømte beskrivelse (i et brev til vennen Niethammer) af Napoleon som Verdens Ånd inkarneret. Slottets facade bar nemlig årstallet 1807, som er det år Hegel fra sine vinduer i Jena så Napoleon ride gennem gaderne på sin lille grå hest, og samtidig udgav Phänomenologie des Geistes. ${ }^{7}$

Alle disse spøgelser - Napoleons, Hegels, Åndsfænomenologiens - medvirkede muligvis til at afskrække officeren fra at give ordre til at nedbrænde slottet? $?^{8}$ Dette ville i givet fald være en eklatant uretfærdighed.

Pointen er, at fortælleren skriver: »Men Hegel vidste at skelne mellem det empiriske og det essentielle« $\left(L^{\prime} i\right.$, p. 6). Og den sene hegelianer, eller posthegelianer Blanchot anerkender naturligvis, omend indirekte og ironisk, denne skillelinje. Der kan altså ikke være tale om at postulere et ligefremt skel mellem livets eksistens og dødens essens. Den allersidste sætning i skitsen siger jo netop også udtrykkeligt: »mit dødsøjeblik herefter for altid for retten/stillet i bero « ( $L ' i$, p.10) - dødsøjeblikkets momentane cæsur perpetueres ind i en tidslig uendelighed, »altid«. De to momenter transponeres ind over hinanden og sameksisterer, de afløser ikke hinanden i en kausal rækkefølge.

Man kan for at klargøre dette, importere Blanchots skel i anden sammenhæng mellem »død«og »døen«. I L'espace littéraire (Dansk: Det litterære rum) fra 1955 beskriver Blanchot en litteratur-ontologisk bevægelse fra døden som stoisk og dialektisk mulighed, til en umulighed af at kunne dø,

7. Allerede her er en diskret ironisk distance til Hegel tænkelig. Paul Virilio gengiver uden reference i sin Hastighed og politik (da. ovs. Kbh. 2001) følgende: „Hegel, som beundrede de franske revolutionære, skrev i januar 1807 til en ven: „Enhver franskmand har lært at se døden i øjnene«», Virilio op.cit., p.20.

8. Jfr. desuden på dette punkt en militær og rumslig omvending: fra Napoleons indtrængen på tysk territorium, til nazisternes penetration af fransk ditto; samt endnu en omvending: den sejrrige Napoleon overfor de slagne og flygtende tyskere. Gentagelsen i historisk tid er med andre ord formet som en svækket repetition: tyskerne gør denne gang, som Napoleon oprindelig (gjorde), men kun i en langt svagere og affældig form. Tyskerne er i den forstand "besejret» af Napoelons oprindelige arke-skikkelse, evokeret af slottets årstal. 
en vedvarende afdøen. Blanchot spørger retorisk, »er jeg istand til at dø?«og svarer: »I den menneskelige horisont, er døden ikke det der er givet, men det der resterer at blive gjort. ${ }^{9}$

Hvad Blanchot mener er, at hvis vi som mennesker skal erobre dødsbevidstheden og gøre den til en komponent i vores erfaringsrum, er det ikke nok bare passivt at hengive sig til den langsomme, gradvise fysiske død, og sige at "man dør«, og længere er dén ikke. Det er kun ved en suveræn og fri akt, at vi kan tilegne os denne erfaring af det i sig selv uerfarbare: "Mennesket dør, det er ingenting, men mennesket er til overfor sin død, han allierer sig med den, på en plads hvor han (selv) er dommer, han gør sin egen død, han gør sig dødelig, og giver - derved - sig (selv) magten til at skabe sin egen betydning og sandhed. $«^{10} \mathrm{Og}$ Blanchot tilføjer, at det er i Hegels, Nietzsches og Heideggers tankebevægelser, at vi på denne måde kan opnå at gøre døden til en mulighed og en opgave.

Lad mig kort opsummere det tidslige skisma på tekstens bagside, før jeg videre befatter mig med dødens problem. Problemet består i, at Blanchot orkestrerer en systematisk, ikke-dialektisk modsigelse mellem en empirisk og en essentiel tidsforståelse. Basis er individets endelighed, det faktum, at vi ikke er udødelige væsener, men er overgivet til dødens banale hændelse. Blanchot siger da i første runde, at den unge mand vækkes af sin antropologiske slummer ved at blive rykket ind umiddelbart foran sit døds-øjebliks indtræffen. Han siger, at denne begivenhed, der kommer i stand ved at selve dødens hændelse pludselig forhindres, er bestemt ved at tiden momentant stopper. $\mathrm{Og}$ han tilføjer, at dette vendepunkt kommer til at få afgørende indflydelse på den tidslige modalitet som regulerer resten af individets levetid. Dette skal forstås på den måde, at den følelse af lethed, som dødsøjeblikket avlede, i det resterende livs forløb vedvarer.

Der er ikke uden videre tale om, at manden er hen-rykket fra livets eksistens til dødens essens - at han mandigt, stoisk og virilt har erobret en essentiel døds-mulighed, og at denne erobring fremkalder en fornemmelse af lethed, sejrens sødme.

Nej, det gælder omvendt at han passivt er hengivet til en permanent afdøens domstol, "altid for retten«. Det er netop ikke »døden selv« han erfarer, men mere præcist selve dødsøjeblikkets transposition ind i en uophørlig afdøens tilstand. Han trækkes passivt hen foran pelotonen, han afbrydes passivt af en af soldaterne og får lov at stikke af, han angribes passivt i den nærliggende skov af følelsen af at virkeligheden vender tilbage, han

9. Blanchot : L'espace littéraire, Paris 1955, p. 118.

10. Ibid. 
udsættes passivt for den arbitrære uretfærdighed, at kun hans familie og hans ejendom skånes for krigens grusomhed.

Det, der resterer for den unge mand, er dermed et umuligt mellemrum mellem den empiriske tid og den essentielle tid. Han er ved ekstasens mellemkomst blevet uigenkaldeligt rykket bort fra den primitive, biologiske og hverdagslige tid, den tid, hvor han ikke ænser tidens gang, men blot bevidstløst nærmer sig dødens ophør. Men han er samtidig på den anden side et til stadighed passivt offer. Offer for en logik der ikke tillader ham at være den maskuline erobrer af døden-som-mulighed, den værdige arvtager af Hegels, Nietzsches og Heideggers robuste endeligheds-filosofier. Derrida citerer i en længere tekst om L'instant, Demeure ${ }^{11}$ Blanchot selv: »Døden er, i absolut henseende, den uophørlige nærhed, hvorved livet ikke desto mindre holder ud ved at begære. Nærheden af det der altid allerede har fundet sted. ${ }^{12}$

Han kan med andre ord hverken dø eller afdø. Hverken ørkesløst og usynligt være i færd med at dø uden at sanse det, eller aktivt og synligt erobre visheden om den egne og tilegnede dødsbegivenhed, som en sand, åndsfænomenologisk Ridder af Ereslegionen.

Tekstens første linjer artikulerer dette dilemma: »Jeg erindrer en ung mand - en mand endnu ung - forhindret $\mathrm{i}$ at dø af døden selv - og måske (af) uretfærdighedens fejltagelse« ( $L^{\prime} i$, p. 2). Han kan hverken blive borger for døden »udenfor ham», den empiriske død, eller døden »i ham«, den essentielle død ( $L^{\prime} i$, p. 8). Vennen Derridas titel, Demeure - dette ord betyder bl.a. bosted eller hjemsted, har på dette punkt relevans. Og jeg vil allerede her foreslå, at tekstens unge mand netop kun kan bebo det umulige dødsøjeblik, der hverken ligger udenfor ham eller indeni ham.

Der står bogstaveligt, at denne neutrale unge mand, »en ung mand«, forhindres $\mathrm{i}$ at dø af døden selv, og måske af uretfærdighedens fejlgreb. Denne kryptiske formulering udpeger to kilder til forhindringen: Døden selv og muligvis uretfærdigheden, mere specifikt dens fejlgreb.

Det er vigtigt at holde sig for øje, at begge instanser er ulegemlige og uhåndgribelige. I tekstens fiktionale verden virker de med stor kraft, men deres mandat og deres manifestation er konsekvent usynlige. Der er hverken tale om en deus absconditus, om gemen obskurantisme, eller om et plat deus ex machina-greb, men derimod om en kølig præmis, en ubrydelig lov for tekstens post-revolutionære univers.

11. Derrida: L'instant, Demeure, Paris 1998. Se også note 1.

12. Op. cit. p. 49. Derrida citerer fra den engelske oversættelse af L'écriture du désastre. Jfr. for en grundig redegørelse for Derridas Blanchot-læsning, Frederik Tygstrup: „Grænsens poetik«, i: Ny Poetik, nr.2 (1993), pp.60-75. 


\section{Efter revolutionen.}

"Post-revolutionære«, fordi skitsens tidslige register ikke mindst er forsynet med en gradbøjning af historicitetens fænomen. Rammen for erindringen er en elementært historisk begivenhed, komplet med datoer, stedsangivelse, detaljer m.m. - ikke et utopisk værested frigjort fra den historiske erfarings klæge smuler. Og fordi Blanchot i sit store essay om Litteraturen og retten til at dø (1949) skriver følgende om forbindelsen mellem revolutionens begivenhed og litteraturen: „Sådanne epoker kalder man Revolution. I dette øjeblik håber friheden på at virkeliggøre sig i den umiddelbare form hvor alting er muligt, hvor alt kan lade sig gøre (....) Den revolutionære handling er på alle punkter analog med den handling litteraturen inkarnerer: en overgang fra intet til alt, en bekræftelse af det absolutte som begivenhed og af hver begivenhed som absolut. $\|^{13}$

Det er på dette punkt indlysende, at Blanchot i L'instant beskriver en tilstand emfatisk efter revolutionen. Hegels Napoleon kom ridende efter den franske revolution 18 år tidligere; nazisterne er på flugt fra ruinen af en perfid drøm om revolution og en ny verdensordens fødsel, og selv skribentens suveræne frihed er smittet af den skrøbelighed, som revolutionens sammenbrud fører med sig. Teksten er spækket med modifikationer og tilbagetrækninger i form af "peut-être« og vedføjede spørgsmålstegn, lige som flere sætninger indsætter en subtil glidning mellem viden og forestilling, fx: »jeg ved, forestiller jeg mig $(\ldots) \ll\left(L^{\prime} i\right.$, p. 8), eller: »jeg ved - ved jeg - at den (...)« ( $L^{\prime} i$, p. 4).

Kernen af dette er imidlertid, at den unge mand endnu en gang passivt og næsten idiotisk er overgivet til en realitet, hvor den absolutte frihed, som selve revolutionen i sit udspring lovede, er fordampet og borte.

Den unge mand er dermed af strukturelle grunde forhindret $i$ at tåle døden og bevare sig selv i den, som det hedder hos Hegel i $1807 . .^{14}$

Her er tale om en fundamentalt non-hegeliansk bevægelse, et a-dialektisk greb, der gør den unge mand hjemfalden til den blotte og bare hjemløse re-

13. Blanchot: Orfeus' blik og andre essays, redigeret af Carsten Madsen og Frederik Tygstrup, Kbh. 1994, p.46.

14. Jfr. Hegel: Phänomenologie des Geistes (org. 1807), Frankfurt a.M. 1988, p.36. Denne komprimerede sætning angiver et indslag $\mathrm{i}$ en lang diskussion af anerkendelsesdialektikken. Her er spillet mellem selvbevidsthedens Herre og Slave bestemt af at gå til døden, og kun den der uden frygt og blusel kan se døden i øjnene og leve med dens akutte nærvær, kan være Herre og mester. Dermed »tåler« Herren døden, og »bevarer« sig selv i den, dvs. gør sig til herre over sin selvbevidsthed, i og med evnen til ikke at frygte døden, men tværtimod at tage den på sig, som en altid levende og nærliggende mulighed. 
gistrering af det virkeliges midt imellem, og lige fjernet fra det brutalt empiriske og det spekulativt essentielle.

Tekstens unge mand går således fra slottets »interieur« til landets »dehors«, nazi-officeren siger: »Udenfor, udenfor« $\left(L^{\prime} i\right.$, p. 2$)$, men det er symptomatisk uklart, nøjagtigt hvor han i udsigelses-nuet befinder sig, hvadenten han er identisk med en yngre udgave af fortælleren, eller blot fortoner sig i det blå. ${ }^{15}$

\section{Dydens jubel}

Man skulle nu tro, at alt dette ville kunne fremkalde et sorgarbejde, en melankoli, en gennemgribende nedtrykthed og tristesse, et traume - men det stik modsatte sker. Tekstens dominerende affektive prædikater er »lethed « (»légèretè»), »lyksalighed « (»béatitude«), "suveræn jubel« (»allégresse souveraine«). Dette sker vel at mærke på baggrund dels af synet af de mange døde unge mænd på egnen, og deres fædres brændende gårde. Dels set i forhold til det tekstens fortæller benævner »uretfærdighedens pinsel«: »Alt brændte, undtagen Slottet. Herremændene var blevet skånet. Sådan begyndte uden tvivl for den unge mand uretfærdighedens pinsel. Ikke mere ekstase« $\left(L^{\prime} i\right.$, p. 6).

Man kunne måske forstå en spontan, euforisk lettelse over at være undslippet den visse død. Men denne efterfølgende lethed og jubel oven på bunken af lig og uretfærdighedens pinsel forekommer bizar og uforklarlig. Der står: „Følelsen af lethed (...) resterede ikke desto mindre, som jeg ikke ved hvordan jeg skulle oversætte: frigjort fra livet? Det uendelige som åbner sig? Hverken lykke eller ulykke« (L'i, pp. 6-8).

Den sidste dobbelte afgrænsning (hverken lykke eller ulykke) peger indirekte på en del af forklaringen på denne lille gåde. Der er ikke tale om psykologiske tilstande slet og ret, om psykologisme. ${ }^{16}$ Det sted, fortælleren benytter sig af ordet »béatitude«, dvs. lyksalighed, forklarer han nonchalant i en parentes: »(dog intet lykkeligt derved)«( $L^{\prime} i$, p. 4). Lyksaligheden er ikke uden videre navnet på en tilstand, hvor subjektet er lykkeligt. Denne leksikografiske og psykologiske spærrebom fordrer en forklaring.

15. Dette markerer et brud med den tankebane Michel Foucault udfolder i sit lille essay om Blanchot fra 1966, La pensée du dehors, Montpellier 1986. Ifølge nærværende tolkning propelleres den unge mand ud i et mellemrum mellem interioritet og eksterioritet, Blanchots "neutrale«nulpunkt.

16. I denne henseende er Blanchot en lydig elev af Husserls og Heideggers gennemgribende kritik af "psykologisme«: den opfattelse, at bevidsthedstilstande restløst lader sig begribe og analysere som psykologiske tilstande slet og ret. Problemet er, at psykologismen antager det der skulle forklares, nemlig hvorledes bevidsthedsakter konstitueres. 
En del af forklaringen skal søges ved at gå til Spinozas Etik, og til den franske nietzscheaner Clément Rosset.

\section{Dydens suveræne magt: Spinoza}

Jeg skal først citere to steder fra Benedikt Spinozas Etik. ${ }^{17}$ Det indledende citat stammer fra Etikkens fjerde bog (der handler om muligheden for at styre vore lidenskaber, at opnå magt over følelserne, og derved blive lykkelige), dens 73. læresætnings 4. afsnit. Og siger: „Det er fremfor alt nyttigt i livet at fuldkommengøre forstanden eller fornuften, så vidt vi kan, og alene heri består menneskets højeste lykke eller lyksalighed; thi lyksaligheden er jo ikke andet end selve den tilfredshed i sindet, der opstår af den intuitive erkendelse af Gud«. ${ }^{18}$ Spinozas panteistiske rationalisme dekreterer, at »lyksalighed«, på latin »beatitudo«, følger af den mest muligt aktive mobilisering af forstanden, hvor den højeste grad af fornuft ytrer sig som den intellektuelle kærlighed til Gud og dyden.

Andet citat kommer fra femte bogs 42. læresætning og siger: „Lyksaligheden er ikke dydens løn, men selve dyden; og vi glæder os ikke ved den, fordi vi hæmmer lysterne; men omvendt, fordi vi glæder os ved den, derfor kan vi hæmme lysterne.« - herefter følger Spinozas bevis, more geometrico: „Lyksaligheden består (...) i kærligheden til Gud, og denne kærlighed opstår jo (...) af den tredje art erkendelse, ${ }^{19}$ og følgelig må denne kærlighed (....) henføres til ånden, for så vidt som den er aktiv; og følgelig er den selve dyden.«-Denne salut afsluttes således: »og fordi den menneskelige kraft til at hæmme følelserne består alene i forstanden, glæder altså ingen sig ved lyksaligheden, fordi han har hæmmet følelserne; men magten til at hæmme lysterne opstår tværtimod af selve lyksaligheden. ${ }^{20}$

Det bemærkelsesværdige er her, at Spinoza først sætter magten og forstandens aktive mobilisering (benævnt dyden) som den positive mulighedsbetingelse for kontrol med nydelsen - og ikke omvendt, den bogstavelige hæmning af følelserne og lysterne, der til resultat vil have dydens løn, den intellektuelle kærlighed til Gud.

17. Dansk oversættelse Kbh. 1996.

18. Op.cit., p.179.

19. Spinoza skelner mellem tre typer erkendelse: 1. Den ubestemte eller vage erfaring (indtryk, associationer), 2. Adækvat viden (viden om logisk nødvendige relationer mellem en tings egenskaber), og 3. Intuitiv erkendelse (under evighedens synsvinkel er verden rationelt ordnet). Jfr. hertil Deleuzes udredning af tre parallelle stilbegreber i Etikken, perceptets, affektens og begrebets: "Lettre à Réda Bensmaïa sur Spinoza" (1989), i Gilles Deleuze: Pourparlers 1972-1990, Paris 1990, pp. 223-225.

20. Spinoza op.cit., p.210. 
Jeg citerer fra Spinoza, fordi det er muligt, at Blanchots lille parentes, der sagde, at den unge mands følelse af »béatitude« ikke måtte forveksles med en lykke-stemning, foregår i fuld overenstemmelse med Spinozas forskrift. $\mathrm{Og}$ for det andet, fordi det er tydeligt at store dele af teksten beskæftiger sig med spørgsmålet om loven og retfærdigheden. Ved beskrivelsen af dødsøjeblikkets moment står der: "Snarere følelsen af medfølelse for den lidende menneskehed, lykken ved hverken at være udødelig eller evig « $\left(L^{\prime} i\right.$, p. 4), og jeg har tidligere omtalt »uretfærdighedens pinsel« - langt fra at føle det uretfærdigt at han nu skulle dø, gennemstrømmes den unge mand af lyksalighed ved tanken om sin endelighed, at han gudskelov ikke er uendelig og udødelig. Det hændte sker ikke, som et resultat af, at den unge mand har tøjlet sine følelser af angst og bæven, men omvendt gør den unge mands forstandige magt, hans dyd, ham i stand til efterfølgende at hæmme lysterne.

Blanchot gengiver således omhyggeligt hvorledes den unge herremand stoisk bevæger sig ud af slottet: »skred roligt frem, på en næsten præstelig måde« (L’i, p. 2). Tilsyneladende frygter han intet, han holder hovedet koldt, og det lykkes ham som nævnt at få reddet de kvindelige medlemmer af familien, hvoriblandt hans 94-årige tante, hans mor, samt hans søster og svigerinde.

Selve dødsøjeblikkets cæsur indstifter den unge mands hengivelse til dydens uophørlighed. Dydens følger er nu ikke primært en evne til at hæmme lysterne, men en forøget sans for det virkeliges konstitution. Der står: »Jeg tror han fjernede sig, stadig med følelsen af lethed. [...] Pludselig, i den tætte skov, efter lang tid, genfandt han sansen for det virkelige« $\left(L^{\prime} i, \mathrm{p}\right.$. 4). Jeg forstår dette som en gestus, der markerer en uigentagelig bevægelse fra passivitet til en slynget form for aktivitet. Den unge mand bevæger sig helt konkret videre gennem landskabet, ud af skovens ly, han er som trådt ud af en midlertidig paralyse. Og dette sker med ét slag, "pludselig«, ikke som følge af en gradvis omvendelse. Dødsøjeblikkets tidslige bombe sprænger så at sige med en forsinket detonation.

Men som Gilles Deleuze har gjort opmærksom på, i sin store Spinozamonografi fra 1968, ${ }^{21}$ er den hollandske jøde på sæt og vis komplet amoralsk. Det afgørende er ikke et nærmere, på forhånd defineret sæt af forskrifter, normer eller regler for det moralsk handlende subjekts adfærd. Nej, det altafgørende er den maksimalt aktive udfoldelse af fornuftens kapacitet. Hvis vi antager det sidste er en udlægning af Spinoza, der har et minimalt skær af plausibilitet over sig; ${ }^{22}$ og hvis vi videre installerer dette greb, denne import, i læsningen af Blanchot - da er det muligt at gå et skridt videre i udforskningen af de dunkle linjer om den suveræne jubel, "suveræn jubel? Dødens møde med døden?« $\left(L^{\prime} i\right.$, p. 4). Det er, som om Blanchot på dette sted indsætter en glidende lighed mellem den suveræne jubel, og dødens møde 
med døden, dog i begge tilfælde tempereret af et efterfølgende spørgsmålstegn.

Lad os sige, at Blanchots spørgsmål besvares af den senere formulering som hedder, at den unge mand "genfinder sansen for det virkelige«.

Hvad er her det virkelige? Hvis vi for et øjeblik genbruger det oprindelige skel mellem tekstens to sider af en basal brudflade, ville forsiden sige, at den unge mand midlertidigt blev kastet ud i en følelse af uvirkelighed, og først efter sin pludselige, mirakuløse flugt genvandt sansen for den rigtige, levende, statsautoriserede og pragmatiske virkelighed.

Hvis man med det sidste mener den givne livsverdens evidens, er det vel heller ikke fuldstændig forfejlet. Men der er et problem. Det fremkommer ved slutningen af tekstens første store del, og står som et citat, med anførselstegn. »»Jeg er levende. Nej, du er død«« (L'i, p. 8). Umiddelbart inden denne aparte dialog, skriver fortælleren: "som om døden udenfor ham, herefter kun kunne kollidere med døden $i$ ham.« En integreret del af den unge mands genfundne sans for det virkelige skulle altså bestå i, at han var død, og i at den første død udenfor ham kastede sig mod den anden død indeni ham?

Vi nødsages til at skifte terræn.

\section{Rossets reelle: jublens idioti}

Og dette skal indledningsvis ske ved at indhente Clément Rosset, den store franske, men i Danmark stort set ukendte filosof..$^{23}$ Rosset omtaler i et af sine bedste værker, Le réel. Traité de l’idiotie ${ }^{24}$ en »dyster ækvivalens« mellem begivenheden og ikke-begivenheden, som en direkte følge af dødens realitet.

21. Gilles Deleuze: Spinoza et le problème de l'expression, Paris 1990 (org. 1968), kap. XVI: Vision éthique du monde, pp.. 234-251, samt kap. XIX: Béatitude, pp. 282-298. Jfr. Hertil Michael Hardt: Gilles Deleuze. An apprenticeship in philosophy, Minneapolis 1993, kap.3, "Spinozian practice. Affirmation and joy«, hvor Hardt fint fremstiller Deleuzes »monistiske» Spinoza-abonnement: „Deleuze giver, i den spinozistiske sammenhæng, affirmation en original og præcis definition: Det er et spekulativt princip baseret på værens absolutte singularitet og enhed, eller, med andre ord, værens fulde ekspressivitet«, ibid., p.67.

Hardt præciserer desuden klart den formelle og totale forskel fra og uafhængighed af hegeliansk dialektik denne ontologi indebærer. Langt snarere er der, som hos Clément Rosset, tale om en nietzscheansk tankebane: "Værens fylde, hos Spinoza såvel som hos Nietzsche, betyder ikke alene at væren overalt og altid er fuldt udtrykt, uden noget transcendentalt eller uudsigeligt forbehold. Men også at kraften til at blive afficeret (hvilket svarer til kraften til at eksistere) er komplet udfyldt med aktive og passive affekter «, ibid., p.72. Min påstand er da, at det er konfrontationen med og indgangen i denne tilstandsform Blanchots unge mand udfører efter mødet med sit dødsøjeblik.

22. Cf. for en nærmere redegørelse for Deleuzes udlægning af Spinoza, Cristopher Norris: Spinoza \& The Origins of Modern Critical Theory, Oxford 1991. 
Når vi dør, dør verden og alle dens ting med os, og det hårrejsende faktum, at døden findes - dét Kant kaldte for fornuftens skandale - medfører potentielt en plan udjævning af alt det vi udsættes for, og udsætter andre for. Hertil kommer siden Prædikeren en Vanitas-tradition, der siger at alt er forgængelighed og forfængelighed, at vi hvert øjeblik er i færd med at forsvinde, at vi er levende døde, en slags vitale zombier. ${ }^{25}$ Livets inderste og mest bestandige karakteristikon er da, at det i sig bærer dødens stempel og signatur.

Men dette er nu ikke helheden af Rossets gengivelse af »le réel«. Hans version er ej heller kongruent med Lacans obskure term for det virkeliges ubegribelige uartikulérbarhed.

Ifølge wittgensteinianeren og nietzscheaneren Rosset, er det virkelige først af alt til som idiotisk og gennemført bogstavelig »totalitet«. Det slet og ret tilværende er ikke til som fordobling af sit eget væsen, det er ikke udstyret med imaginære merværdier. ${ }^{26}$ Rossets eksempel på dette stammer fra amerikaneren Malcolm Lowrys Under the Volcano. I denne roman rammes en fordrukken og stangberuset senator meget pludseligt og voldsomt af synet af en blomst på et bord i en restaurant. Han stirrer som en gal på denne blomst, til det øvrige selskabs moro, senatoren ser tydeligvis dobbelt, som det hedder. Rossets påstand er da, at det senatoren ser, er blomsten og intet andet end blomsten, frigjort og løsrevet fra det netværk af symbolske, kulturelle og sociale betydninger, den almindeligvis automatisk er udstyret med. Senatoren rammes af to træk ved det virkelige: At det er til ("anyhow«), $\mathrm{og}$ at det er til netop således (»somehow«). Senatoren ser således i realiteten enkelt, det er alle restaurantens gæster, der ædru og nøgterne går rundt og ser dobbelt. Det er denne enkle omvending af perspektivet, der bærer Rossets beskrivelse af det virkelige som slet og ret til, og i den forstand »idio-

23. Filosoffen Søren Gosvig Olsen oversatte dog engang - i al ubemærkethed - en meget tidlig tekst af Rosset: Brev om chimpanserne (opr. 1965), Kbh. 1983. Mig bekendt gav den iøvrigt ikke synderligt repræsentative tekst aldrig anledning til nogen videre udbredelse af kendskabet til Rossets filosofiske indsats i Danmark eller Skandinavien.

24. Paris 1977.

25. Thomas l'obscur, Paris 1989 (org.1950): „Og havende visheden om på samme tid at være løsrevet fra døden og livet. Han gik, den malede mumie«, p. 42 - for en bemærkning med stor affinitet. Måske man ville kunne lave en riffaterresk kobling tilbage til Théophile Gautiers Le roman de la momie (1889)?

26. Det fælles træk ved Wittgenstein og Nietzsche, som Rosset hæfter sig ved, er afvisningen af den metafysiske opsplitning af verden i en empirisk og en essentiel del, skellet mellem Sein og Schein, mellem Idé-verdenen og den forgængelige, materielle verden. Hos Nietzsche kommer denne afvisning meget tydeligt til orde i fx. Afgudernes ragnarok (org. 1888), da.ovs., Kbh. 1994, cf. pp. 39-41, til fordel for en fremhævelse af verdens foreliggende og enhedslige karakter. Heraf kommer ligeledes opnormeringen af glæde og aggressivitet overfor ressentimentet og slavemoralens dårlige samvittighed. 
tisk«. Virkeligheden skal ikke forstås eller udgrundes. Enten rammes man af den, eller også spinder man sig selv og andre ind i et sindrigt net af konstruktioner af hvad virkeligheden $i$ virkeligheden er gjort af.

Det virkelige er blottet for symbolske, allegoriske eller metaforiske overbygninger. Man skal bide mærke i, at Rosset af samme grund ser Blanchots dystre Godfather, Hegel, som een af de helt store filosofiske banditter, al den stund han er det imaginæres mestertænker. Det virkelige er singulært og fladpandet, og denne bogstavelige realitet kan slet ikke tænkes indenfor rammen af en velvillig empirisme, eller som den absolutte idealismes dialektiske spil mellem empiri og essentialisme.

Hvis vi nu i anden omgang foretager en manøvre der går fra monisten Spinoza til materialisten Rosset, kan vi se, hvorledes denne gradbøjning af forestillingen om det virkeliges beskaffenhed, fuldt ud kan forklare de tilsyneladende selvmodsigende sætninger, teksten citerede: $» » J$ Jeg er levende. Nej, du er død« $\left(L^{\prime} i\right.$, p. 8). Det forholder sig, som Wittgenstein et sted skriver, sådan at alle sætninger altid er både sande og falske. Og i L'entretien infini (1969. Dansk: Den evige samtale/Det evige mellemværende) angiver Blanchot selv denne dobbelthed ved at sætte både plus og minus ud for hver enkelt sætning i dialogen mellem de to unavngivne samtalepartnere. ${ }^{27}$

I dette tilfælde gælder det mere specifikt, at den unge mand og den ældre fortæller (der måske er versioner af det individ der er udstyret med samme, tilbageholdte egennavn), er udsat for en ligning som siger at »jeg« og "du“ på samme tid er levende og døde, sådan at forstå, at de befinder sig i den »dystre ækvivalens«, som Rosset påpeger forekomsten af.

Dette er langtfra det hele. For det gælder jo i anden runde, at denne tilstand på gennemgribende, men ikke-psykologisk måde er karakteriseret ved lethed, lyksalighed og den suveræne jubel.

Lykkeligvis har Rosset skrevet flere kapitler om »jublen« (»l'allegresse»), og jeg vil kort gengive nogle hovedpointer herfra. Rosset definerer et sted »jubelen« som: »viden om det reelle«, ${ }^{28}$ eller »kærlighed til det reelle«.

27. I samme værks afsnit, Le problème de Wittgenstein, der i realiteten behandler forholdet mellem et indenfor og et udenfor i sproget hos Flaubert og Roussel, tilskriver Blanchot, uden henvisning, Wittgenstein opdagelsen af det problem, at ethvert afgrænset sprogligt system er behæftet med den skavank, at vi kun kan sige noget om det udenfor dette system, og så fremdeles i en infinit regres, jfr. L'entretien Infini, Paris 1969, pp. 487-97. Dette forekommer for en første betragtning påfaldende, al den stund sene Wittgensteins opstilling af separate 'sprogspil's regelsæt ifølge een tolkning føres tilbage til en hverdagslig brugssammenhæng der undslipper den infinitte regres' problem, jfr. :» What we do is bring words back from their metaphysical to their everyday use«, Philosophical Investigations, (org. 1953) London 1988, p.48. Men det er også sandt, at Wittgenstein typisk tenderer mod at fremhæve den brugende omgang med hverdagsudtryk som dybt aparte og mærkelig, som ikke-nødvendig, fx: »What gives us so much as the idea that living beings, things, can feel?«, op. cit., p.97.

28. Rosset: L'objet singulier, Paris 1979, p.. 102. 
Rosset afskærmer ligeledes fænomenet fra blot psykologiske følelser, der er ikke tale om følelsen af lykke overfor følelsen af melankoli fx., og han betoner meget stærkt, at konfrontationen med det virkelige på een gang er momentan og permanent, lige som den lykkefølelse mødet producerer er essentielt ubegrundet og ubegrundelig. Lad mig opsummere.

Ifølge Rosset er virkeligheden basalt enhedslig og massiv. Verden er ikke opdelt i flere regioner eller domæner, som religionen eller en stærk tradition i filosofihistorien foreslår det, men den er blot det og det, som nu tilfældigt er foran os, og ikke uden videre kan forsvinde. Virkeligheden er i tilgift blottet for enhver mening eller dybere betydning, den er indifferent overfor os og vore aspirationer, Rosset anvender det græske udtryk »idiotés« for at angive dette præg af partikularitet, simpelhed og enhed.

Det individ, der oplever et møde med det virkelige, kan gribes af en overvældende følelse af lyksalighed. Men selve følelsen er ikke en affektion, en »følelse« i gængs forstand, men en subtil, ekstra-begrebslig form for erkendelse af virkelighedens konstitution, i stil med Spinozas tredje erkendelsesregister. Rosset finder hos Montaigne, Lukretius, Spinoza, Pascal og Nietzsche en særlig fint udviklet sans for denne omstændighed og dette scenarie. Rosset præciserer: „Sådan at jublen ikke blot er en art forsoning med døden og betydningsløsheden; den er også en erkendelsesform, en sikker adgangsvej til det reelle««i. ${ }^{29}$

Mødet med det virkelige kan kun være momentant, men selve lyksaligheden er permanent og vedvarende, og uafhængig af de konkrete livsomstændigheder, vi er nedsunket i. Lyksaligheden kommer før end og producerer mødet med det reelle, ikke omvendt.

Lyksaligheden kan ikke begrundes. Tværtimod: Ser man på verden med uhildede øjne er der tit og ofte grund til tristhed og melankoli og fortvivlelse. Lyksalighedens kraft stammer netop fra dens fundamentalt ubegrundede og ubegrundelige status. Lyksaligheden markerer en uopløselig godkendelse, "approbation« siger Rosset efter Nietzsche, af det virkelige, en extra-rationel og umotiveret anerkendelse af virkelighedens urokkelige karakter af et indifferent sammensurium af ondt og godt, småt og stort, stupidt og begavet, etc. Dette er vel at mærke ikke en forsoning mellem det adskilte, men en stoisk hengivelse til det enhedslige.

Det turde af dette lille landkort være klart, at de tre træk Rosset udpeger - totalitet, lyksalighedserkendelse, mødets idioti - er installeret i Blanchots erindringsskitse.

29. Rosset: Le réel, Paris 1977, p.. 80. 
Sagens kerne er imidlertid, at der hænger en tung, hegeliansk skygge over Blanchots fiktionsverden, og at den distinkte erfaring af tekstens særpræg fordrer, at man skyder dette spekulative tågeslør til side.

Det vil da fremgå, at tekstens to sider af en grundlæggende spalte - det vi kunne kalde for det empiriske og det essentielle - former sig som en nedsat dualisme, der her og der er ganske diskret, men ikke desto mindre ufravigeligt iscenesat.

Men at en endnu nøjere undersøgelse afslører en ironi lige over for Hegel og idealismen. Hegel var jo den der »vidste at skelne«, som Blanchot skriver, mellem netop disse to modi.

Men det anonyme »jeg« og det navnløse »du«, Blanchot indsætter, er på samme tid uendeligt fjernet fra den lidt gumpetunge tyske nazi-officer, han er en art empiriker, kan vi sige, - og fra Hegels overvældende kloge, og ubærligt indskrænkede idealisme.

Blanchot skriver om det unge »du«'s pludselige fornemmelse af lethed: »I hans sted, vil jeg ikke søge at analysere denne følelse af lethed « ( $L^{\prime} i$, p. 4). Følsomhedens og forståelsens hermeneutiske aktivitet skal skrinlægges overfor mødets og det virkeliges abrupte frembrud.

Dermed bliver vi i stand til at konkludere at L'instant former sig som registreringen af en hændelse, nemlig lyksalighedens idiotiske indtræffen, og lethedens og dydens uophørlige nærvær. Blanchot skriver udtrykkeligt, at den unge mand herefter - efter dødens øjeblik - var knyttet til døden med et hemmeligt venskab, »une amitié subreptice« ( $L^{\prime} i$, p. 4).

Derfor kan nogle af de sidste ord være »Hvad betyder det.« Ordene benævner ikke en slap ligegyldighed eller en affabel resignation, men den vågne, lette og jublende erfaring af det uerfarbares restance, det efterslæb af liv i døden, der gud-ske-tak-og-lov ikke lader sig eliminere. ${ }^{30}$

Momentet er samtidig privat og alment. Det er privat ved, at det er mit og kun mit dødsøjeblik, »l'instant de ma mort«, det lader sig ikke uden videre dele i en kollektiv og fælles ekstase.

Men det er samtidig på den anden side anonymt og alment, det er ikke bundet af en paranoisk, juridisk ejendomsret. Dermed undgår det til stadighed at blive trukket for retten, »en instance«. Det udgør helt modsat en fri

30. På dette strategisk vigtige sted hilser Blanchot på de berømte og ofte citerede ord fra Samuel Beckett, se hertil hans anti-nekrolog over Beckett: „Oh tout finir« i Critique, no. 519. 520 (1990), hvor der bl.a. står: »Til Samuel Beckett blev overdraget denne slutningens bevægelse, som intet afslutter«,loc.cit., p. 635. Og netop dette implicerer efter min opfattelse et brud med den hegelianske dialektik, og i særdeleshed den heideggerianske forestilling om »Sein-zum-Tode«, hvor »døden« optræder som navnet på en uoverskridelig grænse - og just derved lader sig erobre som genstand for erfaring. Ikke så hos Beckett - og ej heller hos Blanchot, hvor dødsøjeblikkets grænse og afgrænsning perpetueres i det reelles jublende uafsluttelighed. 
og tilgængelig mulighed for ethvert jeg« og »du«, der ser det og rammes af det, hvis dødens øjeblik vel at mærke passivt overgår subjektet, og subjektet lader sig overgå af det. ${ }^{31}$

Det udpeger en virkelighed. I dette tilfælde - og det er en ikke uvigtig pointe - en essentielt uretfærdig og grim virkelighed. Der står: »Det er krigen: liv for nogle. henrettelsens grusomhed for andre« $\left(L^{\prime} i\right.$, p. 6). En virkelighed, der lader sig erkende som en uopløselig og uoversættelig rest af lethed og glæde, „Der resterede ikke desto mindre, i det øjeblik hvor skydningen ikke var andet end i vente, følelsen af lethed, som jeg ikke ville vide hvordan jeg skulle oversætte« ( $L^{\prime} i$, p. 6). Med Nietzsches ord er verden en fabel, og det er denne uoversættelige og mærkeligt konkrete og bogstavelige fabels konstante overbringelse af dødens øjeblik, Blanchots lille, sene og forsinkede skitse beretter om og portrætterer.

31. Se hertil Jean-Luc Nancys forsøg på at gentænke forholdet mellem singularitet og kollektivitet, med basis i en reformation af ideen om medfølelse, Being Singular Plural (org. 1996), Stanford 2001. Nancys indsats skulle da gøres gældende overfor tekstens brug af betegnelserne »compassion« og »finitude«. Præcis hvilken type »medfølelse« er det den unge mand gribes af, i samme øjeblik han realiserer sit møde med endelighedens nådegave? 